\title{
Surface schooling behaviour of the coastal krill Nyctiphanes australis (Crustacea: Euphausiacea) off Tasmania, Australia
}

\author{
D. P. O'Brien \\ Zoology Department, University of Tasmania, GPO Box 252C, Hobart, Tasmania 7001, Australia
}

\begin{abstract}
Surface schooling by the euphausiid Nyctiphanes australis Sars occurs throughout the year off the east, south-east and north coasts of Tasmania. Direct observations of the schools using SCUBA showed them to be highly integrated with co-ordination comparable to that described for fish schools. Overall school morphology as viewed from the air and underwater was found to be variable between 3 basic forms. The integration within schools and absence of strong passive mechanisms for school formation suggest that it is an active process. The size range of individuals within a school was restricted, although schools are formed at least from the post-larval stage onwards. The sex ratio of $N$. australis schools approximated 1:1. Schooling/swarming in adults is probably related to reproduction, but the causes for swarm formation in sub-adults are unknown, being most likely related to feeding or maturation. $N$. australis is shown to be capable of feeding whilst schooling, and it is suggested that other species of schooling euphausid may also be capable of this given the right conditions. School density ranged from 3000 to $>450000$ individuals $\mathrm{m}^{-3}$, with the biomass for an individual school being as high as $>100 \mathrm{~kg}$ wet weight.
\end{abstract}

\section{INTRODUCTION}

Nyctiphanes australis Sars is restricted to the shallow water neritic regions of the continental shelf of New Zealand (Bary 1956, Mauchline \& Fisher 1969, Jillett 1971) and of southeast Australia from approximately $31^{\circ}$ to $44^{\circ} \mathrm{S}$ latitude, and $132^{\circ}$ to $156^{\circ} \mathrm{E}$ longitude (Blackburn 1980). The importance of $N$. australis in the coastal marine food chain is shown by its predominance in the diet of many commercially important fish and bird species (Table 1), and from evidence showing it to be a major component of zooplankton biomass around the coast, especially during summer (Bradford 1972, Ritz \& Hosie 1982).

Surface swarms of Nyctiphanes australis occur over its whole range, with sightings from Sydney Harbour, N.S. W. (Dakin \& Colefax 1940) to Storm Bay, Tasmania (Ritz \& Hosie 1982), and from South Australia (Sheard 1953) to the east coast of New Zealand, i.e. Dunedin, Otago (J. B. Jillett pers. comm.). However, due to the unpredictable nature of their occurrence, and possibly the costs involved in carrying out a sampling and diving programme from boats, no direct observations have previously been described in the literature. Knowledge of swarming behaviour is therefore derived primarily from net sampling studies of coastal waters around Australia and New Zealand. These studies suggested that: (1) surface swarming is generally a night-time phenomenon with adults aggregating on the sea floor during daylight and rising to the surface in swarms at night (Dakin \& Colefax 1940, Bary 1956, Bartle 1976, Blackburn 1980); (2) it is seasonal (Ritz \& Hosie 1982) and linked to the breeding season (Sheard 1953, Bradford 1972); (3) it occurs generally during the summer in most regions (Sheard 1953, Bary 1956, Bradford 1972, Ritz \& Hosie 1982). However, there are anomalies, with evidence for surface swarming during the day (Fenwick 1973, Hosie 1982, J. B. Jillett pers. comm.), prior to breeding (Mauchine \& Fisher 1969) and during winter (Dakin \& Colefax 1940).

The present study was designed to resolve some of these inconsistencies and to address such specific questions as: Is swarming an active or passive process? How integrated are the individuals within swarms? Is swarming restricted to mature adults? Is there variation in population structure within and/or between swarms? Is swarming confined to certain regions? Are daytime surface swarms a form of aberrant behaviour? Can any 
Table 1 Nyctiphanes australis. Confirmed predators. O: occasional; C: common; D: dependent, at least on a seasonal basis; nd: insufficient data to comment

\begin{tabular}{|c|c|c|c|}
\hline Predator & Species name & Importance in diet & Source \\
\hline \multicolumn{4}{|l|}{ Fish } \\
\hline Southern bluefin tuna & Thunnus maccoyii & $\mathrm{O}$ & Sheard 1953, Serventy 1956 \\
\hline Striped/skipjack tuna & Katsuwonus pelamis & $\mathrm{O}$ & Sheard 1953 \\
\hline Slender tuná & Allothunnus fallai & $\mathrm{D}$ & $\begin{array}{l}\text { Wolfe \& Webb 1975, Bishop et al. } \\
1976\end{array}$ \\
\hline Australian salmon & Arripis trutta & $\mathrm{D}$ & Malcolm 1959 \\
\hline Kahawai & Arripis trutta & D & Bradford 1972 \\
\hline Australian barracouta & Thyrsites atun & $\mathrm{D}$ & $\begin{array}{l}\text { Sheard 1953, Blackburn 1957, this } \\
\text { study }\end{array}$ \\
\hline Australian pilchard & Sardinops neopilchardus & C & Sheard 1953 \\
\hline Jack mackerel & Trachurus declivis & $\mathrm{D}$ & Webb 1976, this study \\
\hline Tiger flathead & Neoplatycephalus macrodon & C & Fairbridge 1951, Sheard 1953 \\
\hline Tarakihi & Cheilodactylus macropterus & $\mathrm{O}$ & Godfriaux 1974a \\
\hline Snapper & Chrysophrys auratus & 0 & Godfriaux 1974b \\
\hline Telescope fish & Mendosma lineatum & $\mathrm{O}$ & Fenwick 1978 \\
\hline Trumpeter & Latris Lineata & C & Fenwick 1978 \\
\hline Various reef fish & $\begin{array}{l}\text { Pseudolabrus sp. and } \\
\text { Notothenia sp. }\end{array}$ & $\begin{array}{l}\text { nd } \\
\text { nd }\end{array}$ & Fenwick 1978 \\
\hline \multicolumn{4}{|l|}{ Birds } \\
\hline Muttonbird & Puffinus tenuirostris & $\mathrm{D}$ & $\begin{array}{l}\text { Sheard 1953, Marshall \& Serventy } \\
\text { 1956, Skira } 1986\end{array}$ \\
\hline Fairy penguin & Eudyptula minor & $\mathrm{O}$ & Gales pers. comm. \\
\hline Fairy prion & Pachyptila turtur & $C, D$ & Bartle 1976 , this study \\
\hline Grey faced petrel & Pterodoma macroptera & C & Bartle 1976 \\
\hline Diving petrel & Pelecanoides urinatrix & 0 & Brothers pers. comm. \\
\hline Silver gull & $\begin{array}{l}\text { Larus novaehollandiae } \\
\text { scopulinus }\end{array}$ & $\mathrm{C}$ & Fenwick 1978, this study \\
\hline Pacific gull & Larus pacificus & nd & This study \\
\hline Cape pigeon & Daption capense & nd & Fenwick 1978 \\
\hline Sooty shearwater & Puffinus griseus & nd & Fenwick 1978 \\
\hline Bullers mollyhawk & Diomedea bulleri & nd & Fenwick 1978 \\
\hline \multicolumn{4}{|l|}{ Others } \\
\hline Humpback whale & Megaptera novaeangliae & $\mathrm{O}$ & Chittleborough 1965 \\
\hline Squid? & & nd & $\begin{array}{l}\text { Ichikawa 1977, 1980: unidentified } \\
\text { krill from Bass Strait in gut contents }\end{array}$ \\
\hline
\end{tabular}

internal (e.g. reproductive success) and external (i.e. changes in the physical environment) cues mediating the behaviour be identified?

\section{MATERIALS AND METHODS}

The majority of direct observations were made in the D'Entrecasteaux Channel and Storm Bay area of southeast Tasmania (Fig. 1; Location Nos. 11 and 9 respectively). Aerial reconnaissance of swarms was made over the Mercury Passage, which lies between Maria Island and the east coast of Tasmania (Fig. 1; Location No.6). All direct observations were made between June 1984 and May 1987.

Individuals were collected using a $20 \times 20 \mathrm{~cm}$ square section handnet ( $1 \mathrm{~mm}$ mesh), towed by a SCUBA diver or 'dipped' in the water from the side of a boat. Aimed hauls were also made on occasions using a $0.5 \mathrm{~m}$ diameter, $1 \mathrm{~mm}$ mesh zooplankton net towed obliquely or vertically through the swarms. Specimens were preserved in $70 \%$ alcohol for subsequent analysis in the laboratory.

The length of Nyctiphanes australis was measured by Standard 1 (Mauchline 1980a). Ovigerous females were categorized as those with egg sacs (ovisacs) containing either eggs or larvae (nauplii), or those whose ovisacs were spent but still attached to the thoracopods. Identification of sub-adult stages follows the brief description by Fenton (1981), although the lengths representing each stage have been modified after Hosie (1982) viz. Furcilia III: length 3.18 to $6.6 \mathrm{~mm}, 5$ pleopods setose; postlarval phase: length 4.75 to $8.95 \mathrm{~mm}$, thoracic gills developing; adolescent phase: length 6.55 to $11.63 \mathrm{~mm}$, thoracic legs and gills fully developed.

Stomach content samples for the fairy prion Pachyptila turtur were collected prior to and during the study 


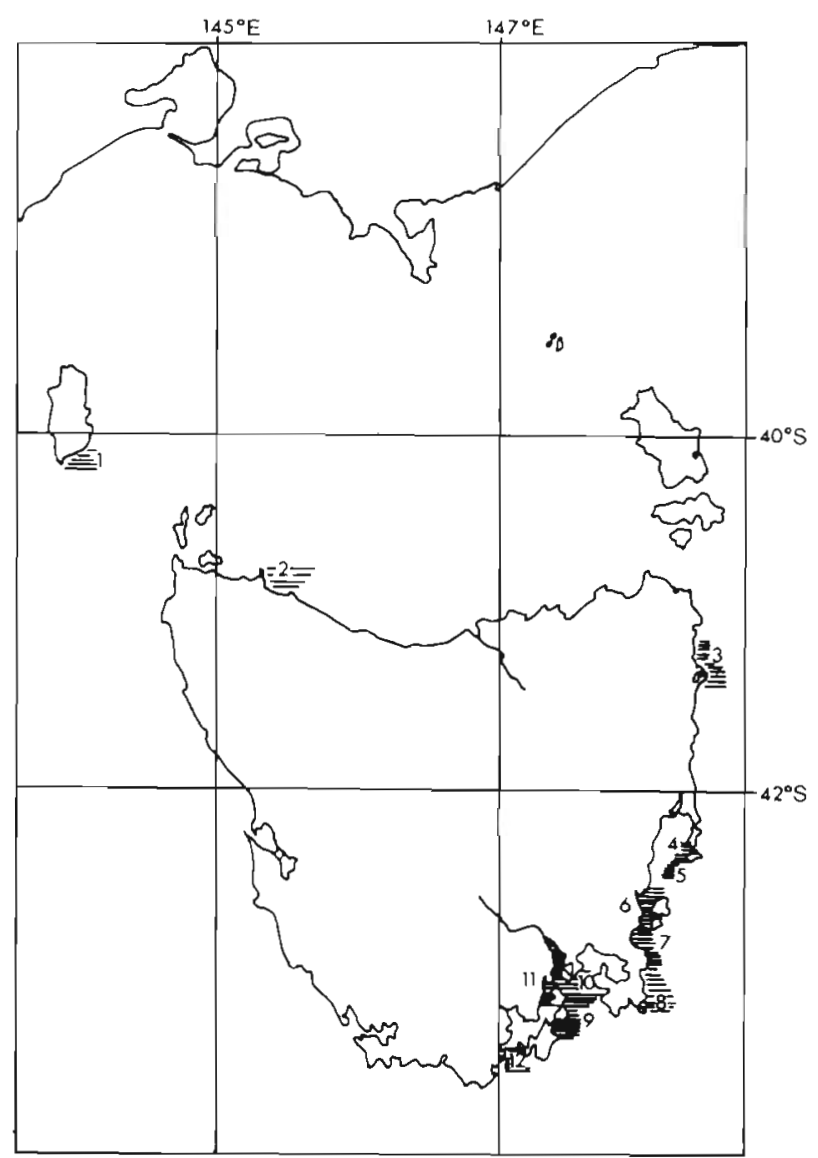

Fig. 1. Nyctiphanes australis. Distribution of daytime surface swarming around Tasmania. Numbers refer to locations giveri in Table 2

period by members of the National Parks and Wildlife Service, Hobart, Tasmania.

All direct observations were made by SCUBA diver, except for aerial observations of surface swarms which were made from a light aircraft. For laboratory observations Nyctiphanes australis were kept in a rectangular perspex holding tank $(1 \times 0.3 \times 0.3 \mathrm{~m})$.

A range of camera equipment was employed: (1) a Canon F1 camera with either a $50 \mathrm{~mm}$ macro lens or a $24 \mathrm{~mm}$ wide angle lens (in an lkelite housing for underwater use) for field, aerial and laboratory still photographs; (2) $16 \mathrm{~mm}$ cinematographic film was shot underwater using a Canon Scoopic in an aluminium housing; (3) the movement of individuals within swarms in the laboratory was recorded on videotape using a JVC GX-N7E video camera suitable for use at low light levels (ca 10 lux).

In the field, swarms were approached from the side in order to cause minimum disturbance, a method of approach previously recommended for Euphausia superba schools by Hamner (1982).

Water temperature and salinity were measured using a salinity-temperature meter (Autolab model 602). Chlorophyll content of surface water was determined by the method of Parsons et al. (1984). Meteorological data were supplied by the Bureau of Meteorology, Hobart, and apply to Hobart City, which is the nearest meteorological data-collecting station to the sites in southeast Tasmania where surface schooling was observed. Tidal information was obtained from the Marine Board Authority of Hobart tide tables for 1984-1986.

The statistical tests used in this study are the 2sample t-test, with ratio data having been modified using the arcsine transformation, and the Mann-Whitney $U$ test (Zar 1974).

\section{RESULTS}

\section{Occurrence}

Areas around the coast where daytime surface swarms of Nyctiphanes australis have been sighted are shown in Fig. 1. There is a bias towards the east and southeast coasts as this is the area investigated in the present study, and the aerial survey of jack mackerel Trachurus declivis fishery is also restricted to the east coast. General dates, times of day and weather conditions for the sightings of surface swarms are given in Table 2. No consistent patterns for temperature, salinity or chlorophyll a content were found for areas in which surface swarms were sighted.

Indirect evidence for the distribution of surface swarms was derived from an analysis of the stomach contents of the fairy prion Pachyptila turtur from the north coast of Tasmania. The fairy prion forages almost exclusively during daylight hours and as it is not a diving bird is restricted to feeding in the top $5 \mathrm{~cm}$ (approx.) of the water column (N. Brothers pers comm.). Stomach contents will therefore reflect prey species present at the water surface during daytime. Qualitative estimates of stomach contents made in the field (N. Brothers pers. comm.), suggest that Nyctiphanes australis is the major constituent of the birds' diet during at least 9 mo of the year (data unavailable for May, July and October). Results from an analysis of $N$. australis population structure in 3 preserved stomach content samples are presented in Table 3.

\section{School population structure}

General data for the composition of swarms and schools found during the study period is presented in Table 3 . 
Table 2. Nyctiphanes australis. Location, season, time of day and general weather conditions for daytime surface swarms. na: no data avaiable

\begin{tabular}{|c|c|c|c|}
\hline Date & Location (Position in Fig. 1) & Time of day $(h)$ & Weather conditions \\
\hline \multicolumn{4}{|l|}{1980} \\
\hline Jun & Shouten Passage (4) & na & na \\
\hline Jul & D Entrecasteaux Channel (11) & na & na \\
\hline \multirow[t]{2}{*}{ Oct } & D'Entrecasteaux Channel (11) & na & na \\
\hline & Mercury Passage $(6)$ & na & na \\
\hline \multicolumn{4}{|l|}{1981} \\
\hline Feb & Off One Tree Pt., Bruny Island (9) & na & na \\
\hline \multicolumn{4}{|l|}{1982} \\
\hline Nov & Adventure Bay, Bruny Island (9) & na & Fine, sunny \\
\hline \multicolumn{4}{|l|}{1983} \\
\hline Jan & Off Clifton Beach (10) & $1200-1500$ & na \\
\hline May & Off Table Cape, Bass Strait (2) & na & na \\
\hline \multicolumn{4}{|l|}{1984} \\
\hline Jun-Jul & Off One Tree Pt., Bruny Island (9) & $0900-1400$ & Rain-sunny \\
\hline Jul & Adventure Bay, Bruny Island (9) & $1200-1800$ & Fine, sunny \\
\hline Jul-Aug & D'Entrecasteaux Channel (11) & $1000-1700$ & Fine, sunny \\
\hline \multicolumn{4}{|l|}{1985} \\
\hline \multirow[t]{4}{*}{ May } & SSE of King Island, Bass Strait (1) & $1200-1500$ & Fine, sunny \\
\hline & Marion Bay (7) & na & Fine, sunny \\
\hline & Eaglehawk Neck (8) & $1200-1500$ & Fine, sunny \\
\hline & D'Entrecasteaux Channel (11) & na & na \\
\hline Jun & Adventure Bay, Bruny Island (9) & $1100-1500$ & Fine, sunny \\
\hline Jun & Off Iron Pot, Cape Direction (9) & $0900-1200$ & Fine, sunny \\
\hline Jun-Jul & Off One Tree Pt., Bruny Island (9) & $0830-1500$ & Fine-overcast \\
\hline Jul & Mercury Passage (6) & $1200-1600$ & Fine, sunny \\
\hline Jun-Aug & D'Entrecasteaux Channel (11) & $0830-1800$ & Rain-sunny \\
\hline \multicolumn{4}{|l|}{1986} \\
\hline Jan & Centre of Storm Bay $(9)$ & na & Fine, sunny \\
\hline Mar & SSW Bruny Island (12) & na & Fine, sunny \\
\hline \multirow[t]{2}{*}{ Sep } & Fortescue Bay (8) & 1500 & Fine, sunny \\
\hline & Off Ile de Phoque (5) & 1200 & Fine, sunny \\
\hline \multirow[t]{2}{*}{ Oct } & D'Entrecasteaux Channel (11) & 1100 & Overcast \\
\hline & Bay of Fire, and off St. Helens (3) & $1200-1500$ & Overcast \\
\hline Dec & D'Entrecasteaux Channel (11) & $1000-1200$ & Fine, sunny \\
\hline \multicolumn{4}{|l|}{1987} \\
\hline Apr & D'Entrecasteaux Channel (11) & $1000-1400$ & Fine, sunny \\
\hline
\end{tabular}

Mean lengths for individuals of each sex within schools are documented in Table 4 . Over $95 \%$ of the schools were composed predominantly of adults, with the mean length over all the schools sampled ranging from 5.73 to $16.7 \mathrm{~mm}$. There was no statistical difference between the lengths of males and females in any of the schools (Table 4), except on 19 Jan 1983, which was the only sample taken from a night-time surface school. There was little variation in the lengths of individuals within any particular school (SD ca $1.3 \mathrm{~mm}$ ). However, there was a small percentage of sub-adults in 2 of the adult schools sampled (Fig. 2A, B).

Individuals in sub-adult schools showed a proportionately larger variation in length from the mean than those in adult schools as shown by their larger coefficients of variation (Table 4).

\section{Results from Lodge Bay, 23 July 1985}

An analysis of variance of mean lengths from samples taken from 6 distinct schools swimming in towards the beach at different times of the day showed a significant difference between the schools (1-way analysis of variance, $p<0.005$ ). Further analysis of the data using Tukeys test revealed that the 2 samples collected later in the day were significantly different in size to one of the samples collected earlier in the morning. However, there was no statistical difference in mean size found between schools collected at or approximately at the same time. 
Table 3. Nyctiphanes australis. General school population structure. SD: standard deviation from the mean; na: not applicable; Stomach conts.: samples taken from the stomach contents of fairy prions Pachyptila turtur

\begin{tabular}{|c|c|c|c|c|c|}
\hline $\begin{array}{l}\text { Date } \\
\text { (time of day) }\end{array}$ & $\begin{array}{l}\text { Length }(\mathrm{mm}) \\
\quad( \pm \mathrm{SD})\end{array}$ & $\begin{array}{l}\text { No. males/no. } \\
\text { females in sample }\end{array}$ & $\begin{array}{l}\% \text { Sub-adults } \\
\text { in Swarm }\end{array}$ & $\begin{array}{c}\% \text { Ovigerous } \\
\text { females }\end{array}$ & $\begin{array}{c}\% \\
\text { Parasitised }\end{array}$ \\
\hline $19 \operatorname{Jan} 1983$ & $15.5 \pm 1.0$ & $173 / 126$ & 0 & 8 & 0 \\
\hline $11 \mathrm{Jul} 1984$ & $13.2 \pm 0.8$ & $128 / 140$ & 0 & 0 & 0 \\
\hline \multicolumn{6}{|l|}{1985} \\
\hline $20 \mathrm{May}$ & $8.8 \pm 1.4$ & na & 94 & na & 0 \\
\hline \multirow[t]{3}{*}{$12 \mathrm{Jun}$} & $12.3 \pm 1.1$ & $39 / 66$ & 3 & 12 & 0 \\
\hline & $13.1 \pm 1.4$ & $42 / 53$ & 3 & 0 & 1 \\
\hline & $5.1 \pm 0.9$ & na & 100 & na & 0 \\
\hline $18 \mathrm{Jun}$ & $13.9 \pm 1.1$ & $158 / 212$ & 0 & 5 & $\sim 1$ \\
\hline 27 Jun & $14.9 \pm 0.9$ & $106 / 109$ & 0 & 0 & 1 \\
\hline \multirow[t]{2}{*}{ 4. Jul } & $13.9 \pm 1.2$ & $163 / 289$ & 0 & 0.5 & $\sim 1$ \\
\hline & $5.7 \pm 1.1$ & na & 100 & na & 2 \\
\hline $10 \mathrm{Jul}$ & $15.4 \pm 1.1$ & $245 / 240$ & 0 & 7 & $<1$ \\
\hline \multirow[t]{2}{*}{$19 \mathrm{Jul}$} & $14.2 \pm 1.7$ & $226 / 169$ & 3 & 1 & 6 \\
\hline & $15.5 \pm 1.1$ & $241 / 199$ & 0 & 8 & 1 \\
\hline \multicolumn{6}{|l|}{$23 \mathrm{Jul}$} \\
\hline (1015 h) & $15.2 \pm 1.1$ & $171 / 220$ & 0 & 5 & 2 \\
\hline (1045 h) & $15.1 \pm 1.3$ & $108 / 113$ & 0 & 8 & 2 \\
\hline$(1130 \mathrm{~h})$ & $15.2 \pm 1.2$ & $240 / 208$ & 0 & 11 & 2 \\
\hline$(1130 \mathrm{~h})$ & $15.5 \pm 1.0$ & $213 / 244$ & 0 & 10 & $<1$ \\
\hline$(1555 \mathrm{~h})$ & $15.6 \pm 1.1$ & $206 / 227$ & 0 & 12 & $<1$ \\
\hline$(1730 \mathrm{~h})$ & $15.6 \pm 1.2$ & $231 / 166$ & 0 & 8 & $<1$ \\
\hline $24 \mathrm{Jul}$ & $15.6 \pm 1.1$ & $29 / 23$ & 0 & 4 & 0 \\
\hline \multirow[t]{3}{*}{2 Aug } & $14.6 \pm 2.0$ & $192 / 168$ & 5 & 11 & 1 \\
\hline & $16.1 \pm 0.9$ & $219 / 67$ & $<1$ & 35 & $<1$ \\
\hline & $15.5 \pm 1.1$ & $72 / 56$ & 0 & 11 & 2 \\
\hline $16 \mathrm{Aug}$ & $16.5 \pm 0.9$ & $219 / 168$ & 0 & 49 & $<1$ \\
\hline 27 Aug & $16.7 \pm 0.9$ & $109 / 126$ & 0 & 63 & $<1$ \\
\hline \multicolumn{6}{|l|}{1987} \\
\hline $16 \mathrm{Apr}$ & $8.3 \pm 1.6$ & $10 / 5$ & 90 & 20 & $<1$ \\
\hline \multicolumn{6}{|c|}{ Stomach conts. } \\
\hline Jù 1984 & $I \bar{f} .4 \pm 0.8$ & $3 / 22$ & 0 & 41 & ? \\
\hline Sep 1985 & $15.2 \pm 0.8$ & $22 / 13$ & 0 & 0 & $?$ \\
\hline Unknown & $17.6 \pm 0.7$ & $2 / 28$ & 0 & 11 & ? \\
\hline
\end{tabular}

\section{Sex ratio}

Of 23 schools analysed, the sex ratio of 12 did not differ significantly from the theoretically expected ratio of $1: 1$. Schools differing from the expected ratio were not dominated by one sex, with the maximum percentage of males or females in a school being 76 and $64 \%$, respectively (Fig. 2H).

\section{Maturity}

Data describing the maturity of swarming adults in terms of the percentage of ovigerous females and the total mean length of all individuals in swarms are discussed together with stranding data by $\mathrm{O}^{\prime}$ Brien et al. (1986).

Sub-adult and adult swarms are defined for the purpose of this study as those comprising $>80 \%$ of their respective maturity stage. Only 5 sub-adult swarms were observed ( $<5 \%$ of the total) over the study period of which samples of individuals were taken from 4. Length frequency data for samples collected from 3 of the swarms are presented in Fig. $2 \mathrm{~A}$ to $\mathrm{C}$. The individual swarms were composed of (1) 20 May 1985: postlarvae $8 \%$, adolescents $86 \%$, adults $6 \%(\mathrm{n}=77) ;(2) 12 \mathrm{Jun}$ 1985: Stage III furcilia $10 \%$, postlarvae $62 \%$, adolescents $28 \%(n=50) ;(3) 4$ Jul 1985: Stage III furcilia $10 \%$, postlarvae $72 \%$, adolescents $18 \%(\mathrm{n}=50) ;(4) 16$ Apr 1987: postlarvae $8 \%$, adolescents $82 \%$, adults $10 \%(\mathrm{n}=144)$.

All sub-adults captured in predominantly adult swarms were identified as adolescents.

\section{Parasites}

The elliobiopsid parasite Thallassomyces fagei (for brief description and life history see Mauchline \& 
Table 4. Nyctiphanes australis. Mean lengths of individuals within swarms. Numbered locations are shown in Fig. 1. Unnumbered locations are all in the D'Entrecasteaux Channel (11); for exact positions see O'Brien at al. (1986). CV: coefficient of variation; na: not applicable; p: significance level using Students t-test, 2-tailed for paired samples, comparing the number of males to females in surface swarms; ns: not significant

\begin{tabular}{|c|c|c|c|c|c|c|}
\hline \multirow{2}{*}{$\begin{array}{l}\text { Date } \\
\text { (Time of day) }\end{array}$} & \multirow[t]{2}{*}{ Location } & \multicolumn{4}{|c|}{ Mean lengths $(\mathrm{mm}) \pm$ standard deviations } & \multirow[t]{2}{*}{$\mathrm{p}$} \\
\hline & & Swarm & $\mathrm{CV}$ & Male & Female & \\
\hline 19 Jan 1983 & One Tree Point (9) & $15.5 \pm 1.0$ & 5.33 & $16 \pm 0.9$ & $15 \pm 0.8$ & 0.0005 \\
\hline $11 \mathrm{JuI} 1934$ & Adventure Bay (9) & $13.2 \pm 0.8$ & 6 & $13.2 \pm 0.8$ & $13.2 \pm 0.9$ & 0.1 (ns) \\
\hline \multicolumn{7}{|l|}{1985} \\
\hline 20 May & Eaglehawk Neck (8) & $8.8 \pm 1.4$ & 15.42 & na & na & nа \\
\hline \multirow[t]{3}{*}{12 Jun } & Off Cape Direction (9) & $12.3 \pm 1.1$ & 8.51 & $12.4 \pm 1.0$ & $12.4 \pm 1.0$ & $0.4(\mathrm{~ns})$ \\
\hline & One Tree Point (9) & $13.1 \pm 1.4$ & 10.45 & $13.4 \pm 1.5$ & $13.1 \pm 1.3$ & 0.1 (ns) \\
\hline & One Tree Point (9) & $5.1 \pm 0.9$ & 17.11 & na & na & na \\
\hline 18 Jun & Alexander Bay & $13.9 \pm 1.1$ & 8.73 & $13.8 \pm 1.0$ & $13.8 \pm 1.2$ & 0.375 (ns) \\
\hline 27 Jun & Off Woodcutter Beach & $14.9 \pm 0.9$ & 5.66 & $15 \pm 0.9$ & $14.8 \pm 0.8$ & 0.1 (ns) \\
\hline \multirow[t]{2}{*}{$4 \mathrm{Jul}$} & Alexander Bay & $13.9 \pm 1.1$ & 8.85 & $13.9 \pm 1.2$ & $13.9 \pm 1.2$ & 0.4 (ns) \\
\hline & Alexander Bay & $5.7 \pm 1.1$ & 19.73 & na & na & na \\
\hline $10 \mathrm{Jul}$ & Off Woodcutter Beach & $15.4 \pm 1.1$ & 6.92 & $15.4 \pm 1.0$ & $15.3 \pm 1.1$ & 0.1 (ns) \\
\hline \multirow[t]{2}{*}{$19 \mathrm{Jul}$} & Robsons Point & $14.2 \pm 1.7$ & 12.11 & $14.5 \pm 1.4$ & $14.5 \pm 1.5$ & 0.4 (ns) \\
\hline & Lodge Bay & $15.5 \pm 1.1$ & 6.81 & $15.5 \pm 1.0$ & $15.7 \pm 1.1$ & 0.1 (ns) \\
\hline $23 \mathrm{Jul}(1015 \mathrm{~h})$ & Lodge Bay & $15.2 \pm 1.1$ & 6.97 & $15.2 \pm 1.4$ & $15 \pm 1.1$ & 0.1 (ns) \\
\hline$(1045$ h) & & $15.1 \pm 1.3$ & 8.81 & $15.1 \pm 1.2$ & $15 \pm 1.4$ & 0.1 (ns) \\
\hline (1130 h) & & $15.2 \pm 1.2$ & 7.8 & $15.5 \pm 1.2$ & $15.1 \pm 1.2$ & 0.025 (ns) \\
\hline (1130 h) & & $15.5 \pm 1.0$ & 6.38 & $15.5 \pm 1.0$ & $15.5 \pm 1.0$ & 0.1 (ns) \\
\hline$(1555 \mathrm{~h})$ & & $15.6 \pm 1.1$ & 7.02 & $15.8 \pm 1.1$ & $15.5 \pm 1.0$ & 0.1 (ns) \\
\hline$(1730 \mathrm{~h})$ & & $15.6 \pm 1.2$ & 7.44 & $15.5 \pm 1.2$ & $15.6 \pm 1.0$ & 0.1 (ns) \\
\hline $24 \mathrm{Jul}$ & Off Coningham Beach & $15.6 \pm 1.1$ & 7.13 & & & \\
\hline \multirow[t]{3}{*}{2 Aug } & Alexander Bay & $14.6 \pm 1.7$ & 11.28 & $15.2 \pm 1.0$ & $15.2 \pm 1.0$ & 0.4 (ns) \\
\hline & Lodge Bay & $16.1 \pm 0.9$ & 5.82 & $16.2 \pm 0.9$ & $15.9 \pm 0.8$ & $0.05(\mathrm{~ns})$ \\
\hline & One Tree Point (9) & $15.5 \pm 1.1$ & 6.87 & $15.5 \pm 0.9$ & $15.7 \pm 1.2$ & 0.1 (ns) \\
\hline 16 Aug & Lodge Bay & $16.5 \pm 0.9$ & 5.23 & $16.5 \pm 0.8$ & $16.5 \pm 0.9$ & 0.4 (ns) \\
\hline 27 Aug & Lodge Bay & $16.7 \pm 0.9$ & 5.24 & $16.6 \pm 0.9$ & $16.7 \pm 0.9$ & 0.1 (ns) \\
\hline
\end{tabular}

Fisher 1969), was encountered in $>70 \%$ of samples collected from surface swarms. Percentages of infected individuals in swarms are given in Table 3 . The maximum number infected did not exceed $6 \%$, and rarely exceeded $2 \%$ for any given swarm. However, on 12 Aug 1985 ( $\mathrm{n}=14)$, and 6 Sep 1985 (both at Lodge Bay in the D'Entrecasteaux Channel), the rate of infection was 14 and $63 \%$, respectively. Both samples were collections of solitary individuals taken right at the water surface, from waters near stranding beaches (O'Brien et al. 1986) a number of days (>2) after the previous stranding event. Of 44 infected individuals analysed from all samples, 18 were male, 25 female and 1 a sub-adult. The length of infected individuals was found to be significantly different from the calculated swarm mean length (Chi-square test, $p<0.05$ ), with approximately $95 \%$ being smaller than the mean.

\section{Behaviour}

In the following, except where stated, the term school density was estimated on the basis of approxi- mations of mean distances from individuals in schools to their nearest neighbours (nearest neighbour distance; NND) in terms of body lengths (dense = individuals $<4$ bodylengths apart approx.). Body length is defined as including the extension of any possible relevant sensory appendages such as antennae and uropod setae and the figure is therefore necessarily an approximation.

\section{External morphology of schools}

\section{Underwater observations}

The shape of dense schools varies between 3 common, basic forms:

(1) Cigar-shaped: generally restricted to larger schools of at least $3 \mathrm{~m}$ in length (Fig. 3A). These schools were always travelling in the direction of their longest axis.

(2) Spherical (Fig, 3B, C): found in small to large 'stationary' schools in which individuals within the swarm were still highly active. 
Fig. 2. Nyctiphanes australis. (A to G) Length frequency histograms. (A, B, C) Schools composed entirely of sub-adults; $(D, E)$ schools composed entirely of adults; $(\mathrm{F}, \mathrm{G})$ mixed schools. (H) Frequency histogram of $\%$ males in all surface swarms sampled
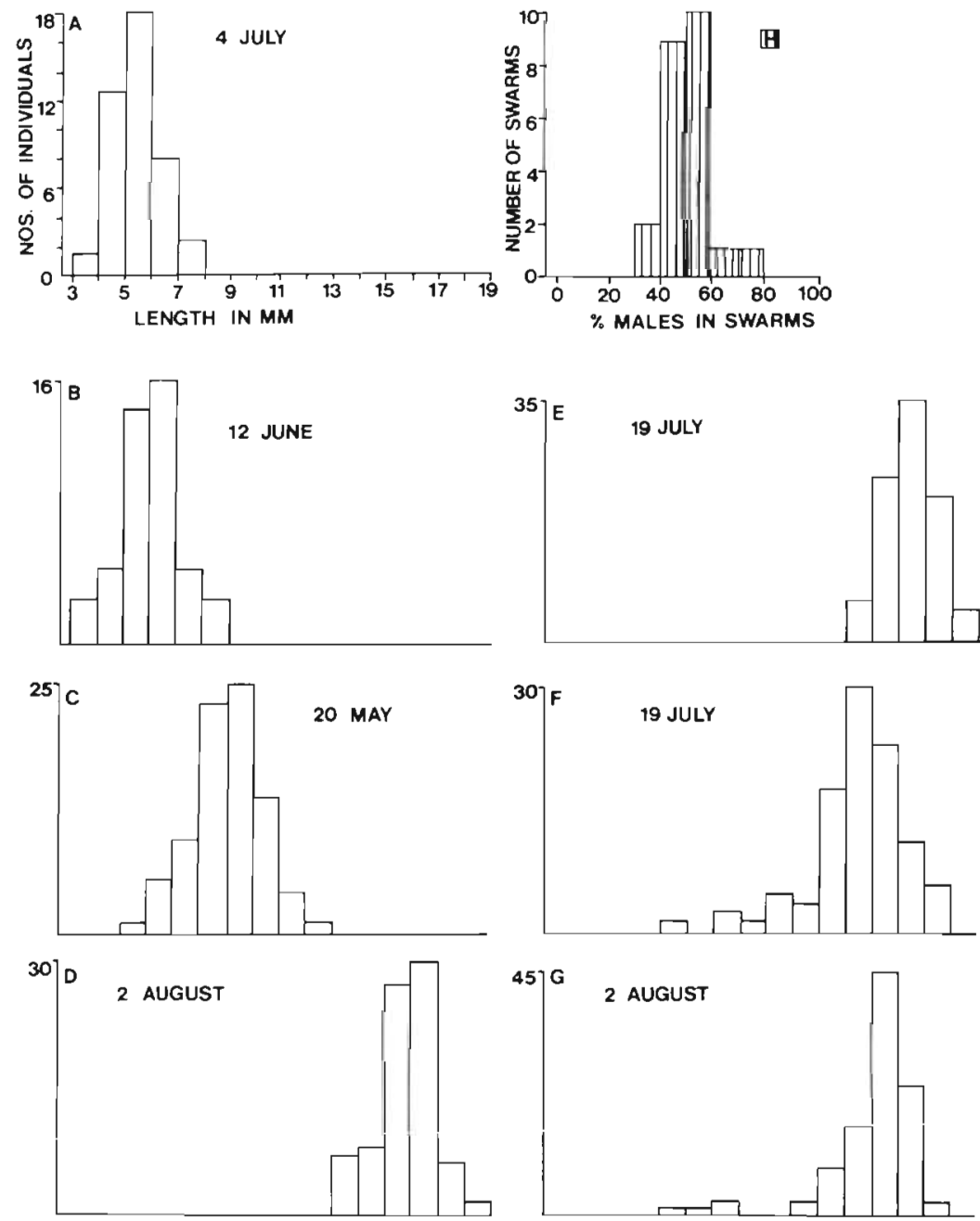

(3) Tear-drop: restricted to small schools $<1.5 \mathrm{~m}^{3}$ approx.), travelling in the direction of the blunt end of their long axis.

The variable nature of school morphology makes it practical to consider the 3 basic forms as points in a continuum, i.e.

$$
\text { Spherical (All sizes) }
$$

Increase in movement of the school as a whole

\section{Cigar (Large-medium)}

Tear-drop (Small)

In the field the most common transient forms were discoid and ovoid. Discoid form was especially prevalent in schools just at the water surface. Larger, less dense schools (Fig. 3E) were generally discoid or ovoid in form, whether maintaining station or travelling in a uniform direction. School size was also highly variable, e.g.:

\begin{tabular}{lcc} 
Form & Smallest & Largest \\
\hline Cigar & $3 \times 0.5 \times 0.5 \mathrm{~m}$ & $15 \times 1 \times 1 \mathrm{~m}$ \\
Spherical & $0.5 \mathrm{~m}$ diameter & $4 \mathrm{~m}$ diameter \\
Tear-drop & $0.5 \times 0.25 \times 0.25 \mathrm{~m}$ & $2 \times 0.75 \times 0.75 \mathrm{~m}$ \\
Discoid & $3 \times 3 \times 0.5 \mathrm{~m}$ & $10 \times 10 \times 2 \mathrm{~m}$
\end{tabular}

Observations of smaller schools ( $<20$ to 30 individuals) were made on numerous occasions (e.g. Fig. 3F), but they were transient in nature arising from the disturbance of a larger school by a diver.

\section{Aerial observations}

Three forms were again seen from the air (Fig. 4): (1) elongate swarms, presumably equivalent to cigarshaped schools; (2) amorphous swarms, probably equivalent to the less dense discoid and ovoid schools; and (3) approximately circular swarms, equivalent to dense spherical and tear-drop shaped schools. Size estimates for 70 swarms were calculated using the formula: 


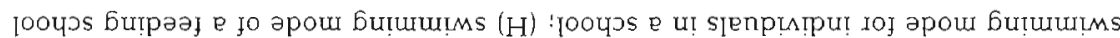

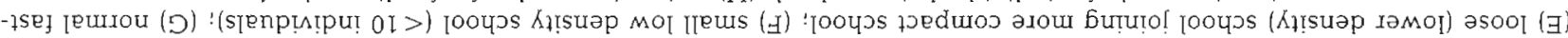

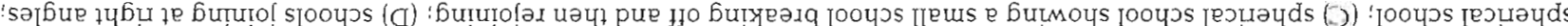

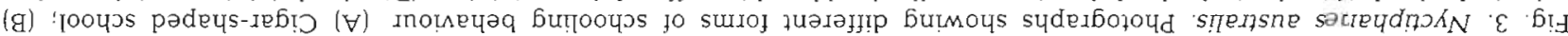
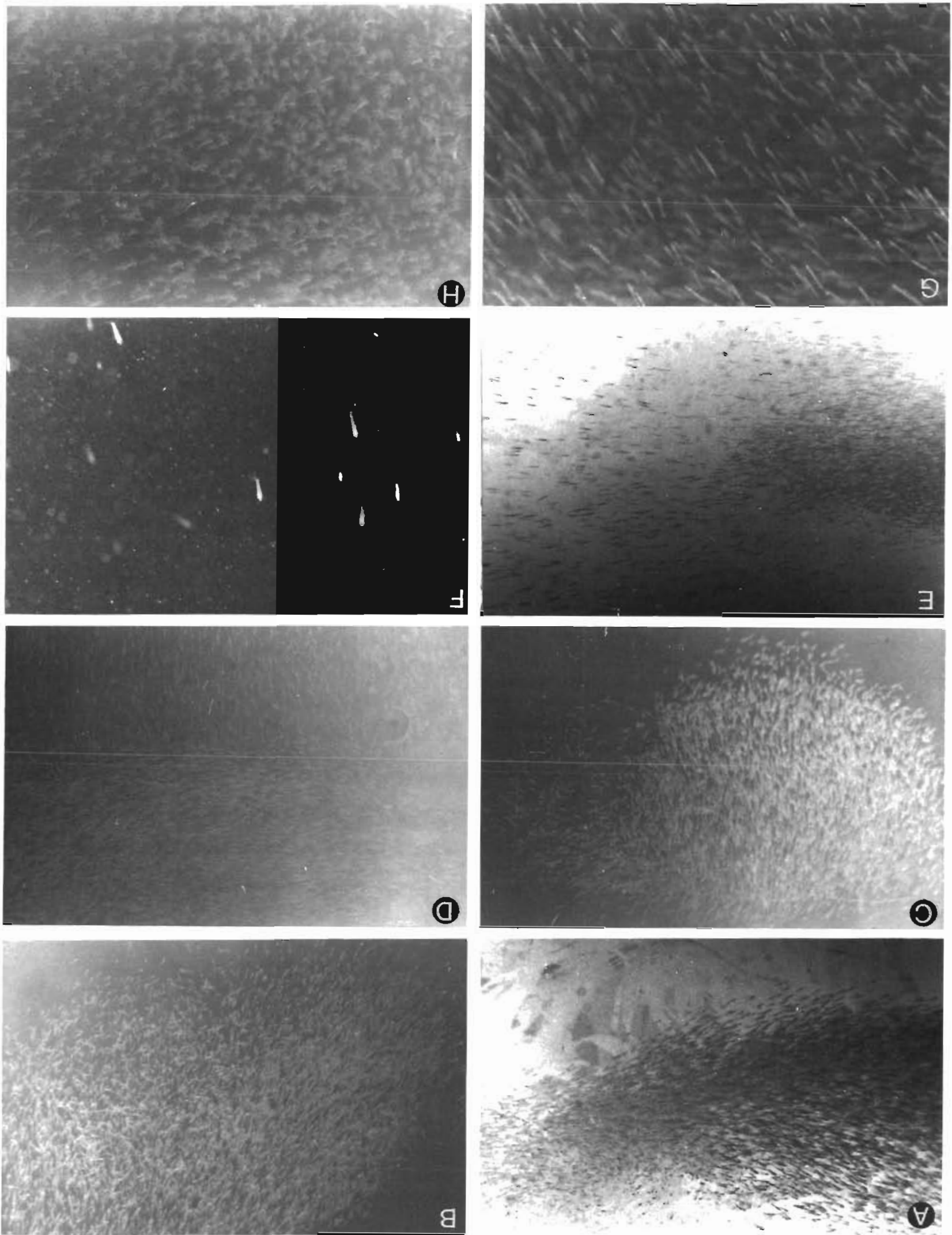
Fig. 4. Nyctiphanes australis. Examples of the 2-dimensional shape of swarms as projected from aerial photographs. (A) Elongated swarms; (B) amorphous swarms; (C) circular swarms. Striped areas represent darker coloured (red) and possibly denser regions of the swarm

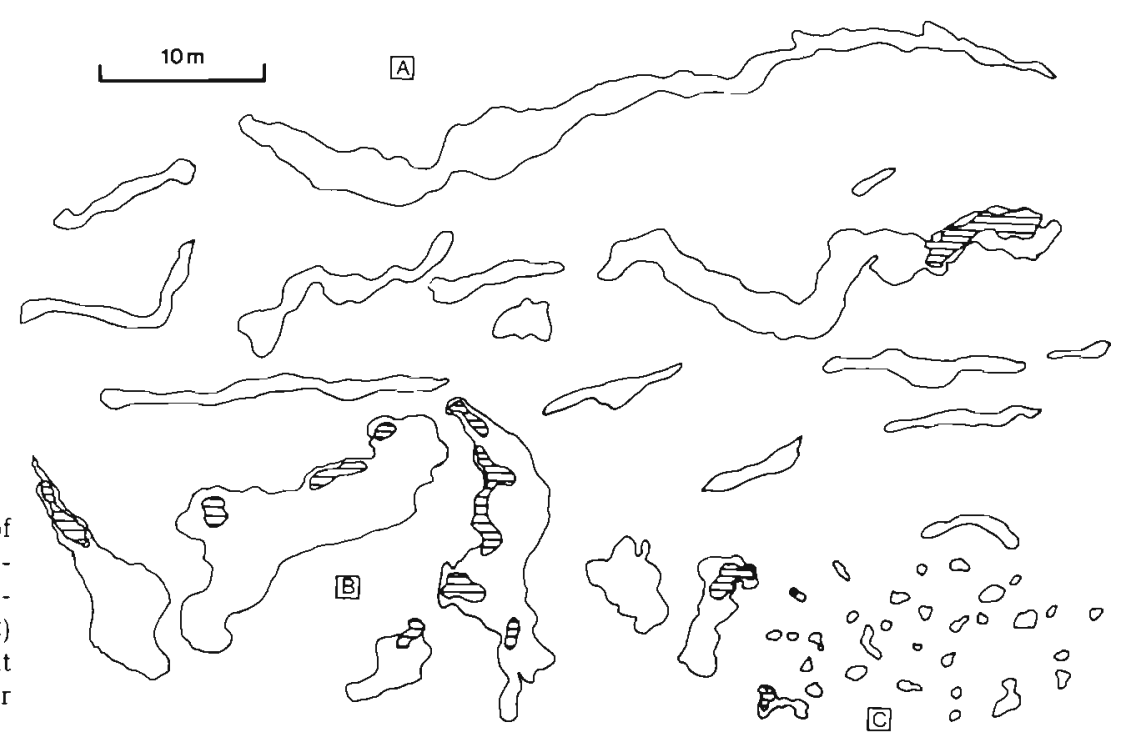

$$
\text { Scale }=\frac{\text { Height above water }}{\text { Focal length of lens }}
$$

with the scale being directly applied to the dimensions of the swarms on the $35 \mathrm{~mm}$ colour slides. However, the height was variable (between 150 and $200 \mathrm{~m}$ ) and the camera was generally not perpendicular to the water surface introducing the possibility of error in the calculations. To compensate for inaccuracy, the scale was calculated using a value of $130 \mathrm{~m}$ for height above water so that all calculations are slight underestimates of the true size of the swarms. The scale was calculated as: $130 \mathrm{~m}: 50 \mathrm{~mm}=1: 2600$ (where $50 \mathrm{~mm}$ is the focal length of the lens). Individuals swarms of all shapes ranged in size from $0.123 \mathrm{~m}^{2}$ to $275 \mathrm{~m}^{2}$.

The total area of the Mercury Passage, east Tasmania, encompassing the swarms was approximately $5 \times 3 \mathrm{~km}$, i.e. patch or shoal size $=15 \mathrm{~km}^{2}$. The area of sea surface occupied by the swarms on the slides ranged from 0.5 to $5 \%$ approx., with the average being $2.8 \%$ (15 slides analysed). Therefore the total area of sea surface occupied by the swarms was estimated to be $0.42 \mathrm{~km}^{2}$.

\section{Internal morphology of schools}

For the purposes of this study this is defined as the relationship between individuals in an aggregation. All krill in aggregations observed using SCUBA during the present study were schooling, all individuals showed parallel orientation and were capable of reacting to an external stimulus as a unit.

The high degree of integration within schools of Nyctiphanes australis is demonstrated by (1) their responses to predators (O'Brien 1987b); (2) responses to stationary obstructions, i.e. cigar-shaped schools observed swimming through dense beds of large, brown algae, Macrocystis pyrifera (Fig. 3A), were able to cohesively avoid the algal fronds by either cascading, as previously described by Hamner (1984) for Euphausia superba, or by splitting the school. In larger schools splitting could occur simultaneously at different points within the school, and in small schools groups of individuals were seen to break contact completely with the major body of the school. However, once past an obstruction the leading edges of split regions would always reform without any apparent disruption to the polarization or packing of the individuals (Fig. 3D, E); (3) continuous movement within dense stationary schools, i.e. spherical aggregations were stationary with relation to their surroundings but were in effect composed of one school or a number of sub-schools of individuals in constant motion (Fig. 3B, C). Once a component school or group of individuals in a school reached its periphery they turned back into the main body, resulting in schools or groups of polarized individuals crossing regularly within the aggregation. When crossing occurred, whether head-on or obliquely there was no breakdown in the polarity of the schools or of the aggregation as a whole. The result was that within the aggregation sub-schools could pass through each other and retain their integrity, amalgamate, or split. However, once the stationary aggregation became mobile for any reason apart from an attack by a predator (O'Brien 1987b), it formed one large highly polarized school which, depending on the number of individuals present, was generally cigar or tear-drop shaped. For this reason the stationary aggregation is termed a school. 


\section{Sub-adult aggregations}

Prolonged observations ( $>1 \mathrm{~h}$ ) were made of the behaviour and morphology of sub-adult surface schools on 26 Jan 1987 in the D'Entrecasteaux Channel (no samples were taken) and $16 \mathrm{Apr} 1987$ in Alexander Bay (eastern side of D'Entrecasteaux Channel). The major features of the schools included polarization of individuals, wider spacing than in adult schools observed in the same localities, and a NND estimated by eye to range from 2 to 6 bodylengths. Mean NND as calculated using an underwater stereophotographic technique (O'Brien 1987a) was approximately 3 bodylengths. The schools were always discoid and restricted to approximately the top $1 \mathrm{~m}$ of the water column. Individual school size ranged from approximately $2 \times 2 \times 0.5 \mathrm{~m}$ to in excess of $5 \mathrm{~m}$ in diameter. School swimming speed was estimated to exceed $10 \mathrm{~cm} \mathrm{~s}^{-1}$ during all observations. Evidence for a strong directional stimulus in the migration of subadult schools was shown at Alexander Bay on $16 \mathrm{Apr}$ 1987, where the general direction of travel was south, away from the beach, and during a stranding on 26 Jan 1987 at Apollo Bay (directly south of Alexander Bay) where the direction of travel was generally north towards the beach, although a few schools were observed swimming in the opposite direction.

\section{Feeding}

Indirect results for feeding and reproduction in winter swarms have been presented in a study on stranding behaviour in Nyctiphanes australis (O'Brien et al. 1986).

Nyctiphanes australis usually swam with the thoracopods held tightly against the ventral surface of the thorax, a straight abdomen and with the antennules extended to the front (Fig. 3G). However, on $11 \mathrm{Jul}$ 1984 at Adventure Bay, all individuals whether in large or small schools of variable density were observed swimming with their filtering baskets continuously open (Fig. 3H). Swimming speed during the response was estimated to be $5 \mathrm{~cm} \mathrm{~s}^{-1}$

\section{Predators}

The only predators observed feeding on surface swarms were silver gulls Larus novaehollandiae, found regularly around the Macrocystis pyrifera beds at One Tree Point, and on 2 separate occasions just south of One Tree Point, Australian barracouta Thyrsites atun were seen to form a 'boil' around a surface swarm with hundreds of fish (ca $20 \mathrm{~cm}$ in length) apparently in a feeding frenzy.
Aerial surveys for jack mackerel Trachurus declivis along the east coast of Tasmania regularly locate the fish feeding on surface swarms of krill $(\mathrm{H}$. Williams pers. comm.).

\section{School density and biomass}

School density was calculated using the cylindrical packing formulae described by Nicol (1986). However, as NND has been estimated by sight, the value ' $\mathrm{d}$ ' in Nicol's formulae has been simplified to be the estimated distance between nearest neighbours and ' $L$ ' refers to the mean total length of a sample of individuals taken from the school. From the value for mean length for individuals in a given school their mean dry weight was calculated from the regression given by Ritz \& Hosie (1982). Biomass of the school (in $\mathrm{g} \mathrm{m}^{-3}$ ) was then simply calculated as no. ind. $\mathrm{m}^{-3} \times$ mean dry weight of the individuals sampled (in g)

The plates in Fig. 3 demonstrate the difficulty in estimating the distances between nearest neighbours from photographs. Observation by diver is more dependable due to the extension of observations into 3 dimensions. Estimates for the NND, density and biomass of a variety of schools observed directly using SCUBA are presented in Table 5. The dimensions of swarms calculated from aerial photographs are not included as there is no direct indication of swarm depth or NND's within the swarms.

The results show that the biomass of individual schools varied from $1 \mathrm{~g}$ to $18 \mathrm{~kg}$ (approx.) dry weight, on the basis that individuals are organised in the closepacked configuration. However, this maximum figure is tentative as the aerial observations demonstrated the occurrence of larger (in area) surface schools than those seen using SCUBA.

\section{DISCUSSION}

Four hypotheses for surface swarming of euphausiids were suggested by Komaki (1967): (1) they congregate at the surface to feed; (2) they are driven to the surface by predators; (3) they are passively brought to the surface by currents or upwelling; or (4) they actively come to the surface to satisfy internal demands related to maturation or reproduction.

Predators were rarely observed in the vicinity of surface swarms, except for 2 species of gull (Larus novaehollandiae, Larus pacificus) found at $>50 \%$ of swarm sites. This discounts the possibility that swarms are driven to the surface by predators, at least on a regular basis. Therefore, the occasional sighting of predators such as jack mackerel and barracouta feed- 
Table 5. Nyctiphanes australis. Range of school density and biomass as calculated from estimates of nearest neighbour distance (NND) and school dimensions from direct observations. Biomass estimate assumes close packing

\begin{tabular}{|c|c|c|c|c|c|c|c|c|c|c|}
\hline \multirow{2}{*}{$\begin{array}{l}\text { Form of school } \\
\text { (qualitative } \\
\text { description) }\end{array}$} & \multirow{2}{*}{$\begin{array}{l}\text { NND (in } \\
\text { body- } \\
\text { lengths) }\end{array}$} & \multirow[t]{2}{*}{$\begin{array}{l}\text { NND } \\
\text { (mm) }\end{array}$} & \multicolumn{2}{|c|}{ Density (no. $\mathrm{m}^{-3}$ ) } & \multicolumn{2}{|c|}{$\begin{array}{l}\text { Dry weight of krill } \\
\text { per } \mathrm{m}^{3}(\mathrm{~g})\end{array}$} & \multicolumn{2}{|c|}{$\begin{array}{l}\text { Volume occupied by } \\
\text { school ( } \mathrm{m}^{3} \text {, approx.) }\end{array}$} & \multicolumn{2}{|c|}{$\begin{array}{l}\text { Biomass of indi- } \\
\text { vidual schools }\end{array}$} \\
\hline & & & $\begin{array}{c}\text { Close } \\
\text { packing }\end{array}$ & $\begin{array}{c}\text { Cubic } \\
\text { packing }\end{array}$ & $\begin{array}{c}\text { Close } \\
\text { packing }\end{array}$ & $\begin{array}{c}\text { Cubic } \\
\text { packing }\end{array}$ & Smallest & Largest & $\begin{array}{l}\text { Smallest } \\
(\mathrm{g})\end{array}$ & $\begin{array}{c}\text { Largest } \\
(\mathrm{kg})\end{array}$ \\
\hline $\begin{array}{l}\text { Cigar, spherical, } \\
\text { discoid ovoid, or } \\
\text { tear-drop shape, } \\
\text { any size, slow } \\
\text { moving }\end{array}$ & 0.5 to 2 & 10.5 to 42 & $\begin{array}{r}500000 \\
31000\end{array}$ & $\begin{array}{r}432000 \\
27000\end{array}$ & $\begin{array}{l}1200 \\
77.5\end{array}$ & $\begin{array}{l}1080 \\
67.5\end{array}$ & $\begin{array}{l}0.065 \\
0.065\end{array}$ & $\begin{array}{l}15 \\
15\end{array}$ & $\begin{array}{r}78 \\
5\end{array}$ & $\begin{array}{l}18 \\
1.2\end{array}$ \\
\hline $\begin{array}{l}\text { Cigar or tear- } \\
\text { drop shape, fast } \\
\text { moving; includes } \\
\text { small discoid and } \\
\text { ovoid schools } \\
\text { and feeding } \\
\text { schools }\end{array}$ & 1 to 4 & 21 to 84 & $\begin{array}{r}125000 \\
7800\end{array}$ & $\begin{array}{r}108000 \\
6750\end{array}$ & $\begin{array}{c}313 \\
19.5\end{array}$ & $\begin{array}{r}270 \\
17\end{array}$ & $\begin{array}{l}0.065 \\
0.065\end{array}$ & $\begin{array}{l}15 \\
15\end{array}$ & $\begin{array}{l}20 \\
1.3\end{array}$ & $\begin{array}{l}4.7 \\
0.3\end{array}$ \\
\hline $\begin{array}{l}\text { Large amorph- } \\
\text { ous, generally } \\
\text { ovoid or discoid } \\
\text { schools }\end{array}$ & 2 to 6 & 42 to 126 & $\begin{array}{r}31000 \\
3500\end{array}$ & $\begin{array}{r}27000 \\
3000\end{array}$ & $\begin{array}{r}77.5 \\
8.8\end{array}$ & $\begin{array}{r}67.5 \\
7.5\end{array}$ & $\begin{array}{l}10 \\
10\end{array}$ & $\begin{array}{l}200 \\
200\end{array}$ & $\begin{array}{r}775 \\
88\end{array}$ & $\begin{array}{r}15.5 \\
1.8\end{array}$ \\
\hline $\begin{array}{l}\text { Sub-adult } \\
\text { schools }\end{array}$ & 3 & 34 & 86000 & 74500 & 120 & 104 & 1 & 12.5 & 120 & 1.5 \\
\hline
\end{tabular}

ing on swarms suggests that the predators' behaviour is opportunistic.

In the general area of Storm Bay and the D'Entrecasteaux Channel (and on the shelf of SE Tasmania) there is mixing throughout the water column and no major upwelling of nutrients (G. Harris pers. comm.). Also the currents measured at the surface were negligible in relation to the measured swimming speed of Nyctiphanes australis, indicating that passive accumulation by horizontal or vertically derived currents is improbable.

Results from the stranding study (O'Brien et al. 1986) indicate that surface swarming at certain times of the year, or stage of maturity of the krill, is directly related to reproduction. However, analysis of swarm composition over the whole range of samples indicates that this is not the universal explanation for surface swarming behaviour, since post-larval and adolescent swarms also exist. Of further interest is the failure to observe mating in daytime swarms, although it was observed in a night-time swarm, suggesting that Nyctiphanes australis may only mate at night. This raises the possibility that swarms come to the surface during the daytime to prepare for mating, and that the accumulation of sub-adult swarms at the surface may be related to maturation or feeding. If school formation is visually mediated and we presuppose that mate recognition and therefore reproductive success is facilitated by aggregative behaviour, then reproductive swarms would be expected to form in daylight.
The observation of feeding schools on only one day during the study suggests that Nyctiphanes australis does not actively congregate at the surface for the purpose of feeding, and evidence from the stranding study suggests that they are not concentrated into certain areas due to localised patches of phytoplankton abundance (O'Brien et al. 1986). It is possible, however, that they may come to the surface in search of food.

\section{School population structure}

Variation in the mean length of individuals within schools was low and is consistent with data published for other species of euphausiid (see Nicol 1984a), although there are exceptions (Nicol et al. 1987). Length frequency analyses of individuals in schools from a localized area suggest that for a given region (depth?), at a certain time of the day, distinct schools may have been derived from the same parent population. However, schools taken from the same region at different times of the day are not derived from the same parent population.

Watkins (1986) found differences between swarms of Euphausia superba at the same time of the day, with variation over several hundred metres being equal to that measured over several kilometres. However, such a scale of measurement and the fact that the samples were taken using an enlarged Longhurst-Hardy plank- 
ton recorder makes it difficult to ascertain whether schools, swarms or shoals were being sampled or integrated. Also Watkins sampled juvenile swarms and evidence from the present study suggests that, at least for Nyctiphanes australis, there is a larger variation in mean size of individuals in schools of immature krill than adults.

The larger variation in the mean size of krill in subadult schools also suggests that either there is a differential rate of growth in immature krill if the swarms maintain integrity throughout their lives, or, as seems more likely, the swarms are in a state of constant flux especially during their immature stages. Segregation into size classes may then take place gradually over a period, especially if swarms continually break up during night-time, as suggested for Euphausia superba by Kalinowski (1978) and Everson (1982), and reform during the daytime. Possible mechanisms for sorting by length include size-dependent swimming speeds (Mauchline 1980b, Hamner et al. 1983) and density/ size dependent sinking rates (Kils 1981b).

The approximation of a $1: 1$ sex ratio in the swarms of Nyctiphanes australis may be related to the fact that there was no difference between the mean sizes of the males and females in the schools. There would therefore be no sexual segregation of the swarms due to differential swimming speeds, as suggested for the highly skewed sex ratio in Meganyctiphanes norvegica by Nicol (1984a). Sex ratios of $N$. australis found in the stomachs of fairy prions were highly skewed indicating that the variation may be either regional, i.e. the samples were taken from the north coast of Tasmania, or that it is predation dependent, i.e. fairy prions can locate or/and capture females more easily.

Sheard (1953) proposed an optimal temperature range for Nyctiphanes australis of 12 to $18^{\circ} \mathrm{C}$, within which the incidence of the elliobiopsid parasite was zero. Results from the present study tentatively support his hypothesis, with regular incidence of the parasite in samples taken from winter swarms, inhabiting waters generally $<10^{\circ} \mathrm{C}$. Also the only sample taken from a summer swarm did not contain any elliobiopsid parasites.

\section{School morphology and behaviour}

Behavioural observations show that the form of schools is plastic, and is related to the overall size and motion of the swarm. Schools are highly integrated as shown by their density and coordination between individuals. Integration is comparable to that seen in obligate fish schools (Partridge 1982), especially with regard to the array of escape responses displayed. The adaptive significance of the variable form of escape response of this species is discussed by O'Brien (1987b).

Nicol (1986) described 3 general shapes of Meganyctiphanes norvegica swarms as seen from the air: smail circular swarms, swarms with globular heads and elongate tails equivalent to the elongate swarms described in the present study, and amorphous or amoeboid swarms. These descriptions are almost identical to the 3 general shapes described here for Nyctiphanes australis. The majority of Euphausia superba swarms observed from ships and described by Nemoto et al. (1981) were circular to elliptical in shape, with even elongate or amorphous swarms tending to be derived from the general elliptical form. The probable explanation is the discrepancy between aerial and high-point (see Mauchline 1980c for definition) observations. Shipboard observations tend towards being 3-dimensional in contrast to the 2-dimensional aerial observations. Aerial photographs do not describe swarm shape per se, they only describe the area of sea surface that a swarm occupies if its horizontal boundaries are extended to the surface. Shipboard estimates are restricted to smaller swarms (tens of metres) due to the restricted field of view of the observer, and are subject to the natural disturbance caused by the presence of the ship, especially when underway. Therefore one would expect ship observations to be biased towards smaller faster-swimming swarms (from descriptions of their escape reactions; O'Brien $1987 \mathrm{~b}$ ) and the increase in the relief of the swarms would give the impression that they were elliptical or ovoid, as is probably the case in 3 dimensions.

Aerial observations of the decapod Munida gregaria (Zeldis \& Jillett 1982, Jillett \& Zeldis 1985), provide evidence for the passive accumulation of aggregations due to physical processes, i.e. convergent water flow and downwelling due to coastal fronts and internal waves. The form of the aggregations described in the present study and of aggregations of Meganyctiphanes norvegica (Nicol 1986) and Euphausia superba (Nemoto et al. 1981) suggest that euphausids do not accumulate at internal waves or coastal fronts in the same manner as described for $M$. gregaria. However, these observations remain to be tested using comprehensive hydrographic data, as suggested by Zeldis \& Jillett (1982).

The method of feeding observed during the present study has previously been described by Kils (1983) for Euphausia superba as a 'get all there is' method, suitable at low food concentrations. No water samples were taken during the observations; however, the water visibility was excellent $(>30 \mathrm{~m})$, suggesting that concentrations of particulate matter (i.e. possible food sources) in the water column were low at the time of feeding. Occurrence of feeding within swarms has 
Table 6. Densities of euphausiid swarms as calculated from estimations of nearest neighbour distance (NND) by direct observation or photography

\begin{tabular}{|lccl|}
\hline Species & Density $\left(\mathrm{nos} . \mathrm{m}^{-3}\right)$ & Length $(\mathrm{mm})$ & Source \\
\hline Euphausia crystallorophias & $100-30000$ & $16-20$ & O'Brien 1987C \\
Euphausia lucens & $4000-1500000$ & $10-20$ & Nicol et al. 1987 \\
Euphausia pacifica & $10-72000$ & $12.3-21.5$ & Hanamura et al. 1984 \\
Euphausia superba & $20000-60000$ & $>30 ?$ & Ragulin 1969, Hamner et al. 1983 \\
Euphausia vallentini & $70000-80000$ & $<30$ & Ragulin 1969 \\
Meganyctiphanes norvegica & $9000-770000$ & 35 & Nicol 1985 \\
Nyctiphanes australis & $3000-480000$ & $15-18$ & This study \\
\hline
\end{tabular}

already been suggested by Antezana et al. (1982) for $E$. superba; however, in contrast, Pavlov $(1969,1974)$ and Hamner (1984) have stated that school structure in E. superba disintegrates during active or rapid feeding. The results from the present study suggest that feeding/schooling are not mutually exclusive among all schooling euphausiids, and furthermore, given the right conditions, probably related to food concentration and the behavioural state of the organism, krill will feed in schools.

\section{Biomass and density approximations}

The school densities calculated for Nyctiphanes australis during the present study compare favourably with those predicted for a euphausiid 15 to $20 \mathrm{~mm}$ in length from the data provided by Nemoto et al. (1981) and previous estimates provided for other euphausiids (Table 6). The larger species Meganyctiphanes norvegica has a relatively higher maximum density than $N$. australis ( $\mathrm{Nicol}$ 1986). This may be explained by reference to photographs of $M$. norvegica swarms (Nicol 1984b) which show individuals to be aggregated at the water surface in a manner reminiscent of the mats, or laboratory-formed clumps and whorls, of $N$. australis described by O'Brien et al. (1986), for which densities of up to $10000 \mathrm{~m}^{-2}\left(>1000000 \mathrm{~m}^{-3}\right)$ were calculated. The swarms of Euphausia lucens described by Nicol et al. (1987) may well have been of similar character.

Wet weight biomass ranged from ca $40 \mathrm{~g} \mathrm{~m}^{-3}$ to $7 \mathrm{~kg}$ $\mathrm{m}^{-3}(\mathrm{WW}=5$ to $6 \times \mathrm{DW}$; Mauchline \& Fisher 1969) in the present study, therefore, the biomass of a cigarshaped school of $15 \mathrm{~m}$ length would be ca $100 \mathrm{~kg}$.

\section{Occurrence}

Surface swarming is a common phenomenon along the whole length of the east and southeast coasts of Tasmania. Indirect evidence from the diet of the fairy prion suggests that it is also common along the north coast, which is supported by occasional direct observations. Combining both direct and indirect evidence, it appears that surface swarming occurs during all seasons, at any time of the day and predominates during fine weather conditions and calm seas; however, the latter conclusion may be a result of the ease of identification of the swarms during such conditions. The possibility of a relationship between reproduction and surface swarming still holds as there is evidence for nearly continuous reproduction for Nyctiphanes australis throughout the year with some indication that there may be seasonal peaks (Jillett 1971, Hosie 1982).

Acknowledgements. I thank Ron Mawbey, Richard Holmes and Roger Kirkwood for their assistance in general field and SCUBA operations, and Dr David Ritz of the Zoology Department, University of Tasmania, for his critical appraisal of tile manuscript and helpful advice throughout the study. I am also grateful for much needed advice and discussion on various aspects of the study provided by Dr Graham Harris CSIRO, Division of Fisheries, Hobart, and Professor John Jillett, University of Otago, Dunedin, New Zealand. Howell Williams of the Tasmanian Fisheries Development Authority made available aerial-based distribution data of surface swarming in Nyctiphanes australis from jack mackerel Trachurus declivis surveys. Nigel Brothers of the National Parks and Wildlife Service, Tasmania provided the fairy prion Pachyptila turtur gut contents and advice on the subject.

\section{LITERATURE CITED}

Antezana, T., Ray, K., Melo, C. (1982). Trophic behaviour of Euphausia superba Dana in laboratory conditions. Polar Biol. 1: 77-82

Bartle, J. A. (1976). Euphausiids of the Cook Strait: a transitional fauna? N. Z. Jl mar. Freshwat. Res. 10: 559-576

Bary, B. M. (1956). Notes on the ecology, systematics, and development of some Mysidacea and Euphausiacea (Crustacea) from New Zealand. Pacif. Sci. 10: 431-467

Bishop, D. G., James, D. G., Olley, J. (1976). Lipid composition of slender tuna (Allothunnus fallai) as related to lipid composition of their feed (Nyctiphanes australis). J. Fish. Res. Bd Can. 33: 1156-1161

Blackburn, M. (1957). The relation between the food of the Australian barracouta, Thyrsites atun (Euphrasen) and 
recent fluctuations in the fisheries. Aust. J. mar. Feshwat. Res. 8: $29-54$

Blackburn, M. (1980). Observations on the distribution of Nyctiphanes australis Sars (Crustacea, Euphausiacea) in Australian waters. CSIRO Division of Fisheries and Oceanography, Report 119: 1-10

Bradford, J. M. (1972). Systematics and ecology of New Zealand central east coast plankton sampled at Kaikoura. N. Z. Oceanographic Institute Memoir 54: 1-81

Chittleborough, R. G. (1965). Dynamics of two populations of the humpback whale Megaptera novaeangliae (Borowski). Aust. J. mar. Freshwat. Res. 16: 33-128

Dakin, W. J., Colefax, A. N. (1940). The plankton of the Australian coastal waters off New South Wales. Part 1. Sydney University Department of Zoology Monograph 1: $1-215$

Everson, I. (1982). Diurnal variation in mean volume backscattering strength of an Antarctic krill (Euphausia superba) patch. J. Plankton Res. 4: 155-162

Fairbridge, W. S. (1951). The New South Wales tiger flathead, Neoplatycephalus macrodon (Ogilby). I. Biology and age determination. Aust. J mar. Feshwat. Res. 2: 117-178

Fenton, G. E. (1981). Production and trophic relations of Nyctiphanes australis G. O. Sars 1883 (Euphausiacea) in the coastal waters of southeast Tasmania. Honours thesis, University of Tasmania

Fenwick, G. D. (1973). Plankton swarms and their predators at the Snares Islands. N.Z. Jl mar. Freshwat. Res. 12: 223-224

Godfriaux, B. L. (1974aj). Food of Tarakihi in Western Bay of Plenty and Tasman Bay, New Zealand. N. Z. Jl mar. Freshwat. Res. 8: 111-153

Godfriaux, B. L. (1974b). Food of snapper in western Bay of Plenty, New Zealand. N. Z. Jl mar. Feshwat. Res. 8: 473-504

Hamner, W M. (1982). Procedures for in situ observations of krill scools in the Southern Ocean. Antarct. J. U. S. 17: 165

Hamner, W M. (1984). Aspects of schooling in Euphausia superba. J. Crust. Biol. (Spec. Iss. 1) 4:67-74

Hamner, W. M., Hamner, P. P., Strand, S. W., Gilmer, R. W (1983). Behaviour of Antarctic krill, Euphausia superba: chemoreception, feeding, schooling and molting. Science 220: $433-435$

Hosie, G. W. (1982). Biology and production of Nyctiphanes australis G. O. Sars, in the coastal waters of S. E. Tasmania. M. Sc, thesis, University of Tasmania

Ichikawa, W. (1977). Report of feasibility study on squid jigging fisheries in the southwestern Pacific Ocean (with particular reference to the waters around Tasmania). Japan Marine Fishery Resource Centre, Japan. Report 18

Ichikawa, W. (1980). Report of feasibility study 1978 on squid jigging fisheries in the southwestern Pacific Ocean. Japan Marine Fishery Resource Centre, Japan. Report 19

Jillett, J. B. (1971). Zooplankton and hydrology of Hauraki Gulf, New Zealand. N. Z. Oceanographic Institute Memoir 53: 1-1.03

Jillett, J. B., Zeldis, J. R. (1985). Aerial observations of surface patchiness of a planktonic crustacean. Bull. mar. Sci. 37 : 609-619

Kalinowski, J. (1978). Vertical migration of krill in the region of South Georgia, February-March 1976. Polskie Arch. Hydrobiol. 25: 573-583

Kils, U. (1981). Size dissociation in krill swarms. Kieler Meeresforsch., Sonderh. 5: 262-263

Kils, U. (1983). Swimming and feeding of Antarctic krill, Euphausia superba, - some outstanding energetics and dynamics, some unique morphological details. Ber. Polarforsch. $4: 130-155$
Komaki, Y. (1967). On the surface swarming of euphausijd crustaceans. Pacif. Sci. 21: 433-448

Malcolm, W. B. (1959). The populations of Australian 'salmon Arripis trutta (Block and Schneider) in Australian waters Aust. J. mar Freshwat. Res. 10: 22-29

Marshall, A. J., Serventy, D. L. (1956). The breeding cycle of the short-tailed shearwater, Puffinus tenuirostris (Temminck), in relation to trans-equatorial migration and its environment. Proc. zool. Soc. Lond. 127: 489-510

Mauchline, J. (1980a). Measurement of the length of Euphausia Superba Dana. BIOMASS Handb. 4: 1-9

Mauchline, J. (1980b). The biology of mysids and euphausiids. Adv. mar. Biol. 18: 1-681

Mauchline, J. (1980c). Studies on patches of krill, Euphausia superba Dana. BIOMASS Handb. 6: 1-36

Mauchline, J , Fisher, L. R. (1969). The biology of euphausiids. Adv. mar. Biol. 7: 1-454

Nemoto, $T$ (1983). Net sampling and abundance assessment of euphausiids. Biol. Oceanogr. 2: 211-226

Nemoto, T., Ishimaru, K., Shirai, T (1981). Swarm of euphausiids in the ocean. Antarctic record. 73: 103-112

Nicol, S. (1984a). Population structure of daytime surface swarms of the euphausid Meganyctiphanes norvegica in the Bay of Fundy. Mar. Ecol. Prog. Ser. 18: 241-251

Nicol, S. (1984b). Krill swarms in the Bay of Fundy. Sea Front. 30: $216-222$

Nicol, S. (1986). Shape, size and density of daytime surface swarms of the euphausiid Meganyctiphanes norvegica in the Bay of Fundy. J. Plankton Res. 8: 29-39

Nicol, S., James, A., Pitcher, G. (1987). A first record of daytime surface swarming by Euphausia lucens in the Southern Benguela region. Mar. Biol. 94: 7-10

O'Brien, D. P. (1987a). Gregarious behaviour in crustacean micronekton (Euphausiacea, Mysidacea). Ph. D. thesis, University of Tasmania

O'Brien, D. P. (1987b). Description of escape responses of krill (Crustacea: Euphausiacea), with particular reference to swarming behaviour and the size and proximity of the predator. J. Crust. Biol. 7 (3): 449-457

O'Brien, D. P. (1987c). Direct observations of the behaviour of Euphausia superba and Euphausia crystallorophias (Crustacea: Euphausiacea) under pack ice during the Antarctic spring of 1985. J. Crust. Biol. 7 (3): 437-448

O'Brien, D. P., Ritz, D. A., Kirkwood, R. M. (1986). Stranding and matting behaviour in Nyctiphanes australis (Euphausiidae: Crustacea). Mar. Biol. 93: 465-473

Parsons, T. R., Maita, Y., Lalli, C. M. (1984). A manual of chemical and biological methods for seawater analysis. Pergamon Press, Oxford

Partridge, B. L. (1982). The structure and function of fish schools. Sci. Am. 246: 90-99

Pavlov, V. Ya. (1969). The feeding of krill and some features of its behaviour. Trudy vses. nauchno-issled. Inst. morsk. ryb. Khoz. Okeanogr. (VNIRO) 66: 207-222

Pavlov, V Ya. (1974). On the relationship between the feeding habits and the behavioural characteristics of Euphausia superba (Dana). Trudy vses. nauchno-issled. Inst. morsk. ryb. Khoz. Okeanogr. (VNIRO) 99: 104-116

Ritz, D. A., Hosie, G. W. (1982). Production of the euphausiid Nyctiphanes australis in Storm Bay, southeastern Tasmania. Mar Biol. 68: 103-108

Serventy, D. L. (1956). The southern bluefin tuna, Thunnus thynnus maccoyii (Castlenau) in Australian waters. Aust. J. mar. Feshwat. Res. 9: 1-43

Sheard, K. (1953). TAxonomy, distribution and development of the Euphausiacea (Crustacea). B.A.N.Z. Antarctic Research Expedition Reports, Series B (Zoology and Botany) 8: 1-72 
Skira, I. J. (1986). Food of the short-tailed shearwater, Puffinus tenuirostris, in Tasmania. Aust. Wildl. Res. 13: 481-488

Watkins, J. L. (1986). Variations in the size of Antarctic krill, Euphausia superba Dana, in small swarms. Mar Ecol. Prog. Ser. 31: 67--73

Webb, B. F. (1976). Aspects of the biology of jack mackerel, Trachurus declivis (Jenyns) from southeast Australian waters. Tasm. Fish. Res. 10: 1-12
Wolfe, D. C., Webb, B. F. (1975). Slender tuna (Allothunnus fallai, Serventy): first record of bulk catches, Tasmania, 1974. Aust. J. mar. Freshwat. Res. 26: 213-221

Zar, J. H. (1974). Biostatistical analysis. Prentice-Hall, New Jersey

Zeldis, J. R., Jillett, J. B. (1982). Aggregation of pelagic Munida gregaria (Fabricius) (Decapoda, Anomura) by coastal fronts and internal waves. J. Plankton Res. 4: 839-857

This article was submitted to the editor; it was accepted for printing on November 23, 1987 